TIGG Vol.2 No.8 (1990)

MEEITING REPORT (TIGG-11/02/90-RM-1)

\title{
A Report on the Seventh FCCA SMAT
}

\author{
Motowo TOMITA
}

School of Pharmaceutical Sciences, Showa University, 1-5-8

Hatanodai, Shinagawa-ku, Tokyo 142, Japan, FAX: 81-3-784-8214

Date: July 17th, 1990, 1:00 pm to 5:00 pm

Plate: Dainippon Insatsu Kenshu Kaikan (1-1-1 Kaga-cho, Ichigaya, Shinjuku-ku, Tokyo)

Organizer: Motowo Tomita

Program: Glycoconjugates of erythrocytes

1. Blood group antigens - Do they have any functions? May-Jean King (Blood Group Reference Lab. United Kingdom)

2. Influenza virus receptors of human red blood cells Seiichi Okuma (Tokyo Coll. Pharmacy, Dept. Biochem.)

3. Biological roles of GPI-anchoring proteins in human erythrocytes Motowo Tomita (Showa Univ. Sch. Pharmaceu. Sci.)

Are you aware of the recent progress on $A B O$ blood groups which has been achieved by the laboratory of Prof. Sen-ichiro Hakomori? The A and B type genes encode $\mathrm{N}$ acetylgalactosaminyltransferase and galactosyltransferase, respectively [refer to TIGG (1990) 2, 387-388]. Ordinary scientists speculated that there were no exciting results to be obtained from the structural analyses of the genes, and I admit that I was one of the very ordinary scientists. Nevertheless, I doubted that Prof. Hakomori had any substantial expectations of getting exciting data at an early stage of his work. However, his results were exciting as follows: 1). Only four amino acid substitutions were observed between the $A$ and $B$ type enzymes, 2). the $O$ type gene had only one base deletion so that active transferase could not be encoded, and 3). only two amino acid substitutions might cause the difference in the enzymatic specificity between $\mathrm{A} 1$ and A2 subtypes. Exciting work allows ordinary persons to speculate on something, and his work was such. Firstly, can such small amino acid substitutions cause the marked change in enzyme specificities? Secondly, it is surprising to know that such small mutations are fixed in every human being all over the world. The points mentioned above were part of the first lecture given by $\mathrm{Dr}$. May-Jean King. Probably you understand that there still remain so many mysteries to be solved on blood groups. Dr. King is a young woman scientist born in Hongkong, and she got her Ph.D. with the study on fucosyltransferase, which was carried out at the laboratory of Prof. Watkins, a well-known scientist on blood groups at the University of London.

The second lecturer was Prof. Okuma who has done excellent work on the relationship of erythrocyte aging with glycoconjugates; structure and functions of sialoglycoproteins as well as MN blood groups. He introduced influenza virus receptors on human erythrocytes. You might simply assume that the major receptor is glycophorin, because hemagglutinin of influenza virus is specific for sialic acids. However, a number of experimental 


\section{富田基䬦}

日時: 平成 2 年 7 月 17 日 午後 1 時 -5 時

会場: 大日本印刷研修センター（市ヶ谷）

オルガナイザー：富田基郎

プログラム:

主題。赤血球の複合糖質

1. 血液型抗原一血液型抗原はなにか機能をもっているか？

May-Jean King (Blood Group Reference Lab., United Kingdom)

2 . 赤血球のインフルエンザウイルス受容体

大熊誠一（東京薬科大学・第二生化学）

3. 赤血球の G P I アンカ一型タンパク群の役割

富田基郎 (昭和大学・薬学部)

A B O 血液型に関する箱守仙一郎先生の研 究室の最近の成果は御存知ですか。A型遺伝 子はNーアセチルガラクトサミン転移䣼を、 B 型遺伝子はガラクトース移転醉素をそれぞ れコードするのですが、これらを構造解析し ても余り感激する知見は得られないだろうと 凡人は見切っていました。何を隠そう、筆者 あ凡人ですが、箱守先生す当初、さほどの成 算があったわけではなさそうです。しかし(1) 両酵索間にはわずか 4 アミノ酸の違いしかな いという結果、(2)○型遺伝子はたった一塩基 の欠損だけで移転酵索がコードできなくなっ ている結果、さらに(3) A 型亜型A1 とA2 る 2 ア ミノ酸置換による酵素特異性变化に起因する らしいという結果はエキサイティングです。 凡人にも想像の翼をくれるのが、エキサイテ イングな研究の証明ですが、上記成果は正に その通りです。まずこのような少しの变異で 醉㚓基質特異性がこんなにる変わってよいる
のでしょうか。次に地球上の全人類にこのよ うな小さな変異が固定されているというのも 驚きです。以上がKing 博士による話の一部 ですが、血液型はまだ謎だらけというのがお 分かりと思います。なお博士は香港生まれの 妙齢の女性研究者であり、血液型で有名な Watkins 教授 (ロンドン大学) の下でフコー ス転移醉素で学位を取られたとのことです。

二番目の演者の大熊先生は赤血球のインフ ルエンザゥイルス受容体について話されまし た。先生は赤血球の aging と複合榶質の相関、 シアロ榶タンパク質の構造と機能、また血液 型に関してもMN血液型などに、優れた業績を 上げておられます。インフルエンザウイルス ・ヘマグルチニンはシアル酸に特異性を持つ ので、その赤血球上の主要受容体はグリコホ リンであろうと簡単に予测するが、そう簡単 ではないようです。実際にプロテオリピッド 分画にも強い受容体活性があることや、ウィ 
TIGG Vol.2 No.8 (1990)

MEEITING REPORT (TIGG-11/02/90-RM-1)

observations suggest that it is not so simple. In fact, he showed that a proteolipid fraction from erythrocyte membranes had strong receptor activity and that the difference in receptor specificity is significant depending on influenza virus subtypes ( $A, B$ and $C)$; for instance the major receptor of $C$ type virus could be gangliosides. Since the receptors without carbohydrate moieties have recently been found with the other kinds of virus, participation of the other portions, besides carbohydrate moieties, might be considered for the receptors of influenza virus.

As the third lecturer, I introduced the GPI-anchoring proteins of erythrocytes. The major subject was a perspective of biological roles of GPIanchoring proteins. Five GPI-anchoring proteins, i.e. acetylcholinesterase, LFA-3, DAF, HRF, and MACIF, are found on human erythrocytes. Although precursors of the GPI-anchoring proteins have the hydrophobic domain in their carboxy terminal regions which appear to be hydrophobic enough to bind to membranes, the hydrophobic domain is cleaved off to be replaced with a GPI moiety. Considerable energy is required for this biosynthetic process. What is the advantage for cells to do this? The first possible advantage is that GPI-anchoring proteins can cover the whole area of the cell surface with a smaller number of molecules compared with the transmembrane proteins, because GPI-anchoring proteins have a higher rate of lateral diffusion. This seems to be a correct answer on complement-related proteins such as DAF, HRF and MACIF. Since the role of DAF is

the decay of $\mathrm{C} 3$ convertase formed on membranes to protect the erythrocytes against complement activation, its GPIform is advantageous to contact the $\mathrm{C} 3$ convertases as fast as possible. HRF and MACIF inhibit the formation of membrane attack complex of self-complement on erythrocytes. Hence, GPIanchoring form is advantageous also for both factors. On the other hand, it seems to be unnecessary for acetylcholinesterase to cleave acetylcholine quickly when the substrate is bound to erythrocytes. Many GPI-anchoring enzymes, including acetylcholinestrase, are likely to produce their products permeable through membranes while their substrates are not permeable. Those enzymes do not require the high rate of lateral diffusion for full expression of enzymatic activity. In view of the points mentioned above, the second possibility on the roles of GPI-anchoring forms is that the forms are advantageous to regulate promptly the number of those molecules. Either proteolytic digestion or endocytosis is necessary for removing the transmembrane proteins from the membranes. Proteolytic digestion is inadequate for this purpose, because the hydrophobic fragments remain on the membranes, crosslinking of membrane proteins via their ligands is usually required for endocytosis; the transmembrane proteins which have no ligands to be crosslinked might have difficulty in regulating (particularly, decreasing) the number of their molecules on the membranes. Then, provided that there are systems responding to quick variation of substrate concentration, GPI-anchoring forms might be more suitable than the transmembrane forms.

Finally, we thank Shimadzu Co. Ltd. for their financial support and exhibiting instruments for sugar analyses. 
ルス亜種（A、B、およびC）による受容体 特異性の違いも無視できない（例えばC型で はガングリオシドが主要受容体の可能性すお る)ことを紹介されました。他のウイルスで は糖鎖の関与しない受容体が、次々に同定さ れているので、インフルェンザについても糖 鎖以外の関与も考えた方がよいとの印象を持 ちました。

三番目の演者として、筆者は赤血球のGPI一 アンカー型タンパク群について紹介したので す。主題はGPI型蛋白質の役割に関する考察で す。ヒト赤血球には、アセチルコリンエステ ラーゼ、LFA3、DAF、HRFおよびMACIFという 5 種類のGPI型タンパク質が見出されています。 GPI型蛋白質の生合成前駆体は C 末端に膜に結 合するに十分な瑓水性をもつぺプチドを持っ ているのに、わざわざその部位を除去して GPI と置き換えています。この過程で消費され るエネルギー量はかなりのすので、それに打 ち勝つだけの利点とは何でしょうか? 一番目 の可能性は、GPI型は膜貫通型蛋白質に比べて 膜平面拡散速度が大きいので、少ない分子数 で膜全面をカバーできるというものです。こ れは補体関連のDAF、HRF、およびMACIFに関し ては納得できます。すなわち、DAFは膜上で形 成された補体C3コンベルターゼを崩壊させて、 自己補体による赤血球の障害を防ぐのが役割 なので、コンベルダーゼに可能な限り早くア
クセスするためにはGPIの方が有利です。まあ HRF とMACIFは自己補体による膜攻撃複合体の 形成を防ぐのが役割なので、これもGPI型の方 が有利でしょう。しかし一方、アセチルコリ ンが赤血球上に結合したとき、アセチルコリ ンを早く除去する必要性があるとは思えない のですが。GPI型䣼菜群の多くは、アセチルコ リンエステラーゼを含めて、基質は表面膜を 透過できませんが、生成物は透過できるよう にする機能をもつように見えます。これらに は拡散速度が大きい必然性はありません。こ のことを考虑すると、二番目の可能性のある 役割は膜上の分子数を速やかに調節するのに、 GPI型が有利であるという考えです。膜貫通型 蛋白質を膜上から除去するには、プロア一ゼ の作用によるか、エンドサイトーシスによら ねばなりません。プロテアーゼ切断では膜上 に㻋水性ペプチドを残すので、賢い方法とは 思えません。エンドサイトーシスには表面上 でのリガンドによる架橋が必要と思われるの で、架橋できないリガンドに対する㻋水性ぺ プチド型タンパク質は分子数の調節（特に減 少）が困難なはずです。そこで状況によって 濃度が大きく変動する基質に対する醉素は、 応答システムがあれば、GPI型の方が有利でし ょう。

最後に糖分析装置を協賛展示していただい た島津製作所に感謝します。 